\title{
Midfacial Degloving Approach for Bilateral Giant Cell Reparative Granuloma
}

\author{
Gaurav Ahluwalia ${ }^{\text {a, b, d, Kishan P. Morwani }}{ }^{\text {a, c }}$
}

\begin{abstract}
Reparative giant cell granuloma is a rare benign tumor. Mandible is the most common site. The case is reported for its rarity in maxilla and difficulty in differentiating it from other giant cell lesions. Differentiation is only based on the clinical test and histopathological examination. Midfacial degloving approach popularized by Caisson et al and Conley in 1974 is best suited for bilateral facial lesions. This approach gives a wide exposure with no facial scar or deformity. The advantages of the degloving technique in exposure of the midface, maxilla, mandible, nasal cavities, and paranasal sinuses, have led to its increasing importance in the otorhinolaryngology.
\end{abstract}

Keywords: Midfacial degloving approach; Giant cell reparative granuloma; Functional diplopia; Sinusitis; Lateral rhinotomy

\section{Introduction}

The term giant cell reparative granuloma (GCRG) was first introduced by Jaffe in 1953 [1] and is a rare benign tumor that occurs almost exclusively within the mandible and maxilla. The second most common location is in the bone of the hands and feet. The etiology of GCRG is uncertain but may be related to intraosseous hemorrhage following trauma.

World Health Organization defines central giant cell granuloma (CGCG) as an intraosseous lesion consisting of cellular fibrous tissue that contains multiple foci of hemorrhage, aggregations of multinucleated giant cells and occasional trabeculae of woven bone $[2,3]$.

GCRGs are classified, according to location, as central or

Manuscript accepted for publication August 15, 2016

aDepartment of Otorhinolaryngology, Dr. Balabhai Nanavati Hospital, Mumbai, India

b Ahluwalia ENT Hospital, Raipur, Chhattisgarh, India

'Sir JJ Hospital, Mumbai University, India

${ }^{d}$ Corresponding Author: Gaurav Ahluwalia, Ahluwalia Hospital, Nemichand Street, Gunj Para, near Prabhat Theatre, Raipur 492001, Chhattisgarh, India. Email: drgauravahluwalia@gmail.com

doi: https://doi.org/10.14740/jcs304e peripheral, occurring, respectively, in bone or gingival soft tissues. In most patients, the tumors are slow to develop, but may recur locally in as many as $50 \%$ of cases, predominantly in children or young adults $(75 \%)$, with a female to male ratio of $2: 1$ [4].

Clinical behaviors of CGCG may be aggressive or non-aggressive, including six criteria [5, 6]: 1) pain, 2) rate of growth, 3) swelling, 4) tooth root resorption, 5) cortical perforation, and 6) recurrence.

\section{Case Report}

A 32-year-old female patient came to the outpatient department of our hospital with complains of bilateral swelling over maxillary area, which was gradual in onset and slowly increasing since last 2 years, and was non-tender. Owing to its location, tumor was disturbing the vision of the patient as well. The growth was large enough to cause disfiguration of face. Patient gave a past history of similar swelling over the left maxillary area which was surgically removed and was reported as fibrous ossifying giant cell granuloma about 4 years back (Figs. 1, 2).

Indications for surgery are cosmetic deformity, gross blockage of nose, obliteration of sinus drainage sinus symptoms, and functional diplopia/intra-orbital extension.

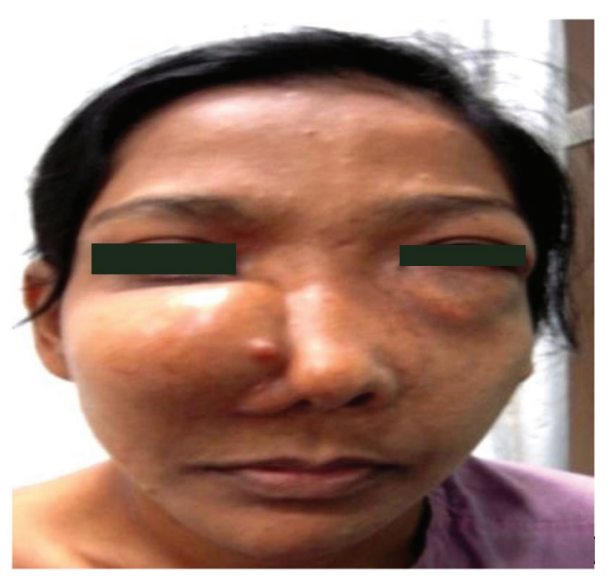

Figure 1. Preoperative patient's image. 


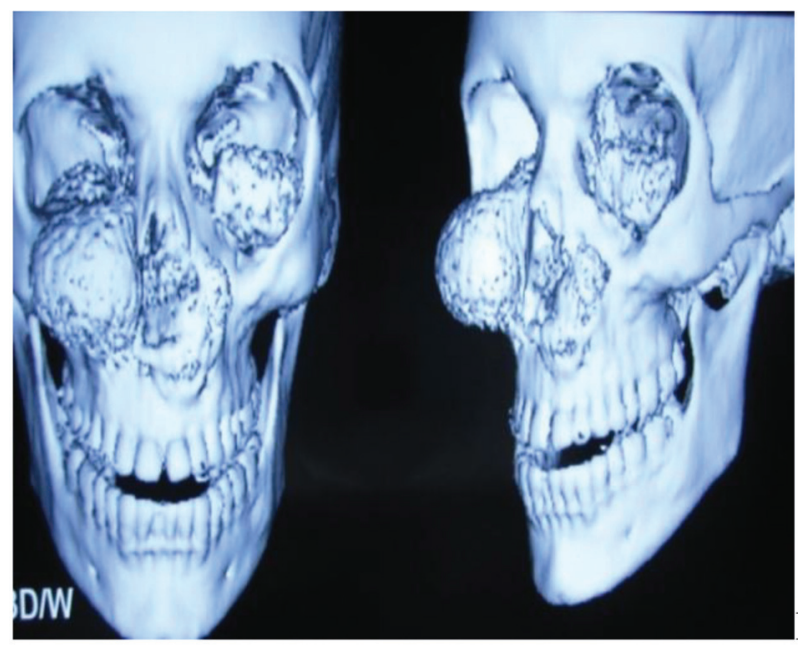

Figure 2. 3D reconstruction images of preoperative computed tomography.

Patient was explained about the natural course of disease. She was convinced to go ahead with surgery. As the lady was young, midfacial degloving approach was best suited for her. Patient was fit for surgery in all preoperative tests and checkups (Fig. 3).

The patient was kept under observation for 1 day and in hospital for 3 days, after which she was discharged on oral medications. Edema subsided gradually (Figs. 4-6) (Courtesy: Dept. of Pathology, Dr. Balabhai Nanavati Hospital, Mumbai, Maharashtra).

\section{Discussion}

The treatment of GCRG is usually surgical. The common proposal for the treatment is surgical excision or curettage and $80 \%$ of the cases can be cured with these modalities. It may recur after incomplete removal in 10-15\% [7].

Chuong et al recommended the use of block resection in aggressive lesion cases that show painful, cortical bone perforation [5]. The recurrence rate has been defined between $11 \%$ and $35 \%$ in the literature [8].

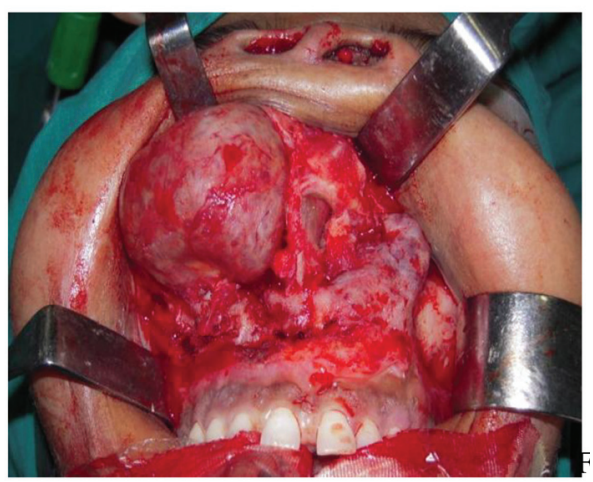

Figure 3. Raising the mass from its base.

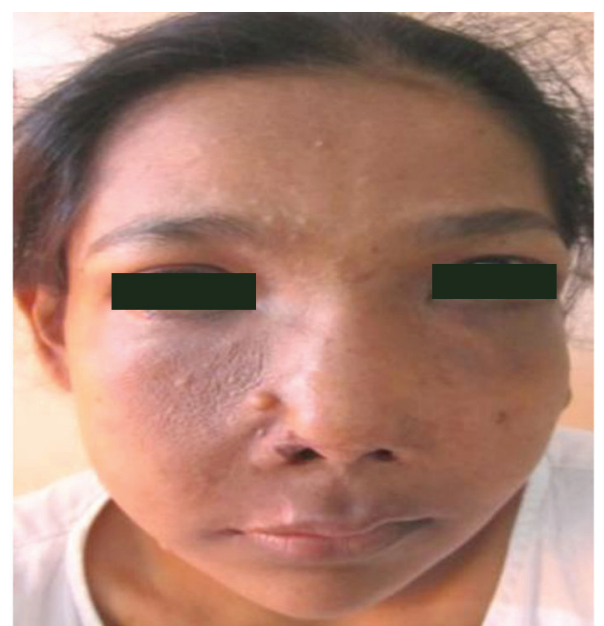

Figure 4. Postoperative after 3 days.

The approach may be repeated if necessary and is associated with few significant complications though vestibular stenosis, oro-antral fistula, nasolacrimal duct damage and upward rotation of the nasal tip may occur. Strategies to avoid these problems can be undertaken and long-term cosmetic results are excellent.

Other possible approaches include lateral rhinotomy, transfacial, Le Fort I osteotomy, external frontoethmoidectomy incision, facial translocation, and midfacial split.

Limitations of degloving approach are tumor invasion into orbit and infratemporal fossa tumor.

Advantages of degloving approach are cosmetically better approach for $\mathrm{B} / \mathrm{L}$, faster recovery, wide exposure, and short hospital stay.

Non-surgical treatments are alpha interferon, calcitonin, and corticosteroids.

\section{Conclusion}

GCRG is a rare benign tumor. Surgery is the most effective treatment for it. Though, recurrences are not very uncommon following residual tumors. Midfacial degloving approach is

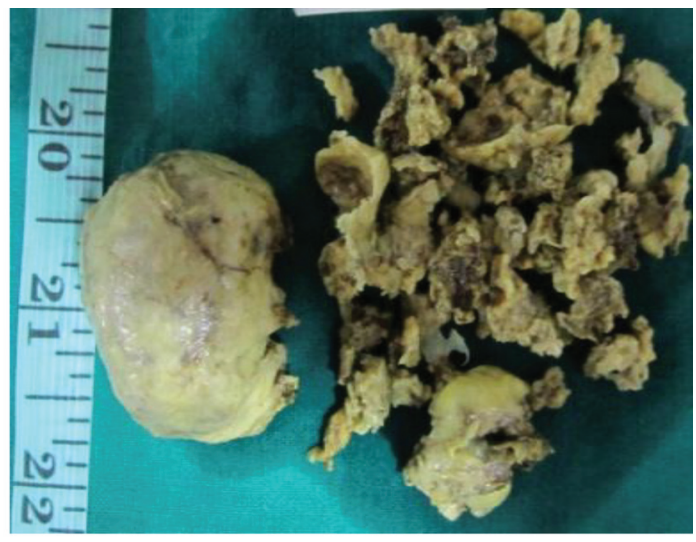

Figure 5. Postoperative specimen. 


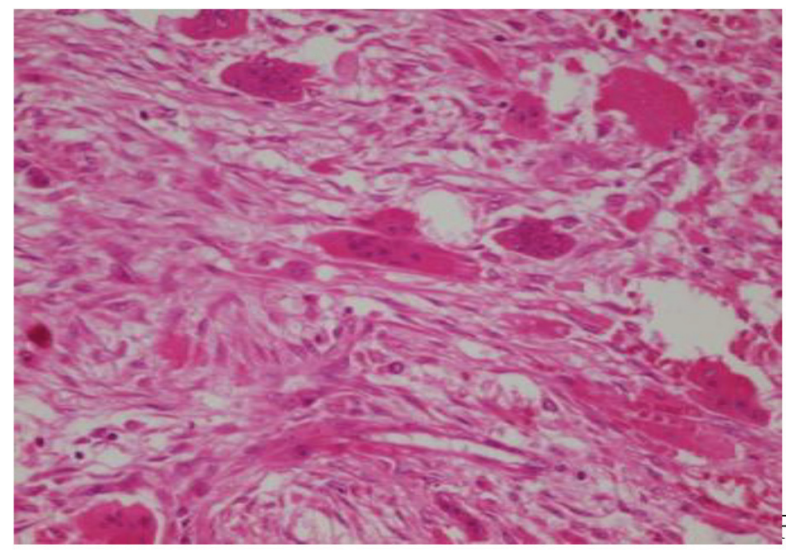

Figure 6. Histopathological slide.

one of the most promising procedures and a relatively underused armament of the otorhinolaryngology fraternity. The procedure is easy, small learning curve, gives no scar to the patient and recovery is fast.

\section{Conflicts of Interest}

None.

\section{Ethical Approval}

All procedures performed in the study involving human participant were in accordance with the ethical standards of the institution and national research committee and with the 1964 Helsinki declaration and its later amendments or comparable ethical standards. This article does not contain any studies with animals performed by any of the authors.

\section{References}

1. Jaffe HL. Giant-cell reparative granuloma, traumatic bone cyst, and fibrous (fibro-oseous) dysplasia of the jawbones. Oral Surg Oral Med Oral Pathol. 1953;6(1):159175.

2. Kruse-Losler B, Diallo R, Gaertner C, Mischke KL, Joos $\mathrm{U}$, Kleinheinz J. Central giant cell granuloma of the jaws: a clinical, radiologic, and histopathologic study of 26 cases. Oral Surg Oral Med Oral Pathol Oral Radiol Endod. 2006;101(3):346-354.

3. Rawashdeh MA, Bataineh AB, Al-Khateeb T. Long-term clinical and radiological outcomes of surgical management of central giant cell granuloma of the maxilla. Int $\mathrm{J}$ Oral Maxillofac Surg. 2006;35(1):60-66.

4. Nancy W. Burkhart. Central Giant Cell Granuloma: Aggressive lesion can cause jaw to swell, and loosen teeth. RDH magazine, 12/23/2015.

5. Chuong R, Kaban LB, Kozakewich H, Perez-Atayde A. Central giant cell lesions of the jaws: a clinicopathologic study. J Oral Maxillofac Surg. 1986;44(9):708-713.

6. Yadav S, Singh A, Kumar P, Tyagi S. Recurrent case of central giant cell granuloma with multiple soft tissue involvement. Natl J Maxillofac Surg. 2014;5(1):60-66.

7. Gunel C, Erpek G, Meteoglu I. Giant cell reparative granuloma in the hard palate. International Journal of Pediatric Otorhinolaryngology Extra. 2007;2(2)76-79.

8. De Lange J, Van den Akker HP. Clinical and radiological features of central giant-cell lesions of the jaw. Oral Surg Oral Med Oral Pathol Oral Radiol Endod. 2005;99(4):464-470. 